\section{The other big bang}

The City of London is entering the twentieth century awkwardly and apprehensively.

MONDAY this week ranks somewhere between a red-letter day and a nightmare for the City of London, equally well-known as the site of most of Christopher Wren's churches and for the much bigger but less tasteful buildings that now house British and international financial institutions. The occasion was dictated by events two years ago, when the British government reached an accommodation with the London Stock Exchange that offered the largest financial market in Europe immunity from anti-trust investigation for unfair trade practices (fixing commission rates on sales of stock) in return for an undertaking that these practices would be abandoned.

To its credit, the London Stock Exchange has, if anything, over-fulfilled its undertaking. Not only are members of the exchange now allowed to charge what commissions they (and their customers) agree, but the membership of the exchange has been broadened and the old restrictions on who may provide what services in the complicated transaction of the purchase and sale of stock have been abandoned. More than that, financial institutions wishing to do business on the London Stock Exchange are now required to be properly computerized. Those in the business of trading in securities, for example, are required to advertise on a generally accessible computer network the prices at which they are prepared to buy and sell, and then to stand by those prices if a customer should come along. Much in the spirit that there can be nothing about the future than cannot be accommodated within a day's work, these arrangements were all to be introduced in earnest at 0900 GMT on Monday of this week. This, by the legend of the past few months, was the City of London's own big bang.

Inevitably, the worst fears of the sceptics seem to have been instantly confirmed. At the appointed time, the spanking new central computer system meant to make everybody's quotations generally available was out of action, overloaded by a torrent of information from dealers marking their cards for the first time. That and an older supplementary computer system providing information about the prices at which deals have been struck appear to have been in and out of action for most of the first two hours of trading. In retrospect, dealers of legendary brashness will probably agree with what systems analysts have been telling them for the past several months, that even high technology requires proving before use. Their immediate response was traditional, to make the gap between buying and selling prices so huge that trading was discouraged, which is hardly the way to make a fortune especially now that commissions are a smaller proportion of sales.

The more serious defect of this week's arrangements is that the regulations by which the British government plans to control the more competitive financial markets are not yet in place. Part of the trouble is that the British House of Commons has been away since the end of July, with the result that the Financial Services Bill is unlikely to become an act for some weeks yet. More seriously, the basis on which the planned regulations have been drawn is an insecure compromise between formal legislation and the City's traditional informality. The intention is that the probity of the City's financial institutions will be assured by a system of 'self-regulation' under which groups of similar institutions will agree to promulgate rules by which they must all behave. Such a system worked well enough when the functions of financial institutions and people were tightly circumscribed in such a way that conflicts of interest were fewer than they will be now. One sign that the government acknowledges the difficulty is its creation of a body to supervise self-regulation, a kind of contradiction in terms. This is the body that has decreed that when a financial institution may be privy to private information about one company's plans to buy another, a "Chinese wall" should separate those concerned from those within the same organization who might make money from the information.

The prospect that such an arrangement will function as intended, as an assurance to the generality of those who deal with London institutions that the insiders do not have an inside track, must be very slim. One big scandal will be enough to blow down the cumbersome system now being installed. The underlying weakness of the planned arrangements is that they are at once unstable and in conflict with the whole objective of the deregulation of the London markets, which is to attract more business from elsewhere in a booming world. The City is fond of the slogan Caveat emptor but may yet find that buyers will exercise the caution demanded of them by taking their business elsewhere so long as the protection of investors seems to rest formally with those who make money from their custom. That would be a pity after all this week's excitement.

\section{Boycott of SDI}

\section{Few are fond of the Strategic Defense Initiative, but a boycott of research would be mistaken.}

DECLARATIONS of intent never to work for the US Strategic Defense Initiative (SDI) Organization have spread from the United States to Britain (see p.747), and will not stop there. Broadly speaking, they will do no harm and probably a little good, if only by reminding the world at large that many wellinformed and well-intentioned people believe that SDI is a waste of their time and other people's money. But there are awkward questions that should be faced by those who will be asked, in the next few weeks, to add their names to the wellfilled dotted lines. Here are some.

From the start of the boycott campaign, it has been supposed that academics will be in the front line, and that those working for industrial research organizations will mostly be unable to commit themselves. That is as it should be, but implies two painful truths. First, the campaign against SDI can be directed on moral grounds against the character of what is planned, for then it would be proper that even industrial researchers should be persuaded to join the boycott. That would be justifiable if, for example, the military were looking for people to work on the manufacture of biological weapons in defiance of an international treaty. The organizers admit that SDI is not in that case by saying that their quarrel is not so much with the dangers it presents (chiefly in the context of bad feeling between the Soviet and US governments) as with the belief that it will not work as planned. But that raises the dilemma of whether it is wise to turn away research money, perhaps when there is none else available, even though there is no prospect of a successful outcome and every prospect that the research itself will be technically interesting.

The moral should be plain. Academic researchers, the recruiters' natural targets, should now as always decide for themselves what research they will undertake. The best topics are the most interesting topics, those most likely to yield understanding of the natural world. SDI topics may often qualify. But choosing for or against SDI research on other grounds (money or politics, for example) is improper (and universities should corporately protest at signs that academic researchers follow such lines of argument). If that principle is kept, the assertion that boycotting SDI is somehow disloyal (in the West) melts away; academic patriotism is the pursuit of the greatest excellence. For people who work in unrelated fields, to whom the dilemma will not be immediate, joining the boycott is an empty gesture but a way of making an interesting point, as if the Pope were to sign a declaration by those not intending to join some society of atheists. The danger in the boycott is merely that it might become coercive, relegating to the doghouse people who, for good reason, of their own, prefer not to take part in such a demonstration. 